\title{
Estimating Volatility in Prices of Pulses in India: An Application of Garch Model
}

\author{
Asha Bisht*1 and Anil Kumar ${ }^{2}$ \\ ${ }^{1}$ Faculty of Agricultural Sciences, SGT University, Budhera-122505, Gurugram, Haryana, India \\ ${ }^{2}$ Department of Agricultural Economics, GBPUA\&T, Pantnagar- 263145, Uttarakhand, India \\ *Corresponding author: asha.pantnagar07@gmail.com (ORCID ID: 0000-0002-5512-0638)
}

Received: 06-04-2019

Revised: 01-07-2019

Accepted: 20-08-2019

\begin{abstract}
Although, India is the largest pulse producing country in the world, the production of these crops in the country has shown sluggish growth over the years. Low growth rate coupled with high fluctuations in production of pulses is mainly responsible for poor performance of pulse sector. It also leads to high price variability. Variability in the prices of pulses is a major concern for decision makers. This study was conducted to estimate the volatility in the prices of major pulses (chickpea, pigeonpea, blackgram, greengram and lentil) in India using GARCH model. Results have shown that the volatility in the current period depends on volatility in the preceding period in case of pulses as evident from the significant ARCH term for all the crops. Further, the sum of $\alpha$ and $\beta$ coefficients has been found more than one for all the pulse crops except pigeonpea in period I thus indicating an explosive price series with a tendency to meander away from mean value. The volatility in the price series of pigeonpea has been found more persistent and explosive in recent period. So, there is a need for regular monitoring of prices and appropriate interventions by the government, when necessary, to make the development of pulse sector more sustainable.
\end{abstract}

\section{Highlights}

(0 The prices of pulses were found highly volatile and this volatility was persistence and do not reverse to mean with time.

Keywords: Pulses, Price Volatility, GARCH model

Pulses serve as a cost-effective and nutritionally balanced rich source of protein to the people of India who are predominantly vegetarian in dietary habits, thereby, forming an important constituent of the food basket. The potential of pulses to help address future global food and nutritional security and environmental sustainability needs has been acknowledged through the UN declaration of the 2016 as 'International Year of Pulses'. India is the major producer, consumer and importer of pulses in the world. India produced 17.15 million tonnes of pulses from an area of 23.55 million hectare in the year 2014-15 with an average productivity of $728 \mathrm{~kg}$ per ha. India produces around 25 per cent of global pulse production from around 35 per cent of global area and productivity of $659 \mathrm{~kg}$ per ha. Chickpea, pigeonpea, blackgram, greengram and lentil are the major pulses grown and consumed in India occupying nearly 84 per cent of the area under pulses and accounting for about 85 per cent of pulse production in the country. Among the various pulses, chickpea dominates, claiming a more than 40 per cent share in production of all pulses grown. Madhya Pradesh, Maharashtra, Rajasthan, Uttar Pradesh and Karnataka are the top five pulses producing states sharing 68 per cent of total pulse production in India. Pulses account for around 20 per cent of the area under foodgrains and contribute around 7 per cent of the total foodgrains production in India (GoI, 2016). 
AESRA

Although, India is the largest pulse producing country in the world, the production of these crops in the country has shown sluggish growth over the years (Bisht, 2018). The stagnant production along with accelerating demand is leading to a decline in per capita availability of pulses and a spiral in prices. The gap between demand and supply of pulses is widening and about 20 per cent of their total demand is yet met by imports. Assurance of stable price environment for growers is very important for increasing agricultural production and productivity. The market price for agricultural produce many a times tends to be unstable and volatile which may lead to suboptimal outcomes compared with those attained under stabilised price conditions. For producers, price volatility may reduce investments and cause production to shift toward lower-risk. Consumers are also negatively affected by the price volatility because of reduced or uncertain access to food. There may also be negative macroeconomic impacts, such as balance of payment, public deficits, and declining total investment because of uncertainty all of which may also have second-round effects on poverty and food security. Therefore, it is imperative to investigate the issues of price volatility that would help policy makers to formulate suitable price policy. A suitable price policy is likely to accelerate and sustain the growth of output by protecting the interest of the farmers on a long-term basis particularly in respect of deficit commodities such as pulses. The objective of our study was to examine the volatility in the prices of major pulses and pulses as a group over time.

\section{DATABASE AND METHODOLOGY}

India is the major producer, consumer and importer of pulses in the world. Chickpea, pigeonpea, blackgram, greengram and lentil are the major pulses grown and consumed in India that account for nearly 80 per cent of total pulse production. This study was conducted for these five pulse crops individually and pulses as a group. The study was based on data extracted from secondary sources. Data on monthly and yearly wholesale price indices of pulses was retrieved from the website of Ministry of Commerce and Industry (www.eaindustry.nic.in) for the period 1996-97 to 2016-17. This period has been further divided into two sub periods viz., Period I (1996-97 to 2006-07) and Period II (2007-08 to 2016-17). Volatility is the sudden unexpected rise or fall in the series. There are various ways of measuring price volatility. In present study, GARCH $(1,1)$ model has been used to get the volatility estimates. ARCH model helps in getting more efficient estimators by handling the heteroskedasticity in the errors properly. GARCH is the generalized ARCH. This model was used in earlier studies also to estimate volatility (Upreti 2015; Anuja et al. 2013; Bhardwaj et al. 2014). The (1, $1)$ in $\operatorname{GARCH}(1,1)$ refers to the presence of a firstorder autoregressive GARCH term (the first term in parenthesis) and a first-order moving average $\mathrm{ARCH}$ term (the second term in parenthesis). The Garch $(1,1)$ model is expressed by the following equation:

$$
Y_{i t}=a_{0}+b_{1} Y_{i, t-1}+b_{2} Y_{i, t-2}+e_{i, t}
$$

Where,

$$
\begin{aligned}
& Y_{i t}=\text { price index in time } t \text { of crop } i . \\
& t=\text { time which takes value } 1,2, \ldots \ldots \ldots, T
\end{aligned}
$$

It is the mean equation written as a function of exogenous variables with an error term.

$$
\sigma_{i t}^{2}=\alpha_{0}+\alpha_{i} u_{i, t}^{2}+\beta_{i} \sigma_{i^{t} t-1}^{2}
$$

Where, $\sigma_{i t}^{2}$ denotes the variance of $e_{t}$ conditional upon information up to period $t-1$. Since $\sigma_{i t}^{2}$ is the one-period ahead forecast variance based on past information, it is called the conditional variance. The conditional variance equation is a function of three terms:

- A constant term.

- Information about volatility from the previous period, measured as the lag of the squared residual from the mean equation: (the $\mathrm{ARCH}$ term).

- Last period's forecast variance: (the GARCH term).

The fitted values of $\sigma_{i t}{ }^{2}$ give the measure of uncertainty of $Y_{i{ }^{*}}$. The sum of $\alpha_{i}+\beta_{i}$ gives the degree of persistence of volatility in the series. The closer the sum to 1 , greater is the tendency of volatility to persist for longer time. If the sum exceeds 1 , it is indicative of an explosive series with a tendency to meander away from mean value. 


\section{RESULTS AND DISCUSSION}

To run the GARCH model, first unit root properties of the series were estimated as time series analysis is based on the assumption of stationary nature of series. For testing the same, unit root test was done on price series using Phillips-Peron (PP) test. PP test is based on nonparametric transformation of model to capture serial correlation in the error term. The results are given in Table 1 . The test results have failed to reject the null hypothesis of unit root in the series at 5 per cent level of significance for all the pulse crops (Table 1) as indicated by the pvalue of more than 0.05 for all the pulses in both the periods. Thus, it confirms the presence of unit root in the series implying that the price series of pulses are non stationary in nature at level. But by taking $1^{\text {st }}$ difference of price series, the test results were found highly significant at 1 per cent level of significance. Thus, it confirms the stationary of price series at their first difference for all the pulse crops.

Table 1: Results of unit root test for monthly wholesale price indices of pulses

\begin{tabular}{|c|c|c|c|c|c|}
\hline \multirow{3}{*}{ Crops } & \multirow{3}{*}{ Period } & \multicolumn{4}{|c|}{ PP test } \\
\hline & & \multicolumn{2}{|c|}{ Level } & \multicolumn{2}{|c|}{ I $^{\text {st }}$ Difference } \\
\hline & & $\begin{array}{c}t- \\
\text { statistics }\end{array}$ & $\begin{array}{c}\mathrm{p}- \\
\text { value }\end{array}$ & $\begin{array}{c}\mathrm{t}- \\
\text { statistics }\end{array}$ & $\begin{array}{c}\mathrm{p}- \\
\text { value }\end{array}$ \\
\hline \multirow[t]{2}{*}{ Chickpea } & Period I & -1.397 & 0.5821 & -4.345 & $<0.001$ \\
\hline & Period II & -1.095 & 0.7164 & -5.405 & $<0.001$ \\
\hline \multirow[t]{2}{*}{ Pigeonpea } & Period I & -2.213 & 0.2028 & -6.731 & $<0.001$ \\
\hline & Period II & -1.724 & 0.4168 & -6.531 & $<0.001$ \\
\hline \multirow[t]{2}{*}{ Blackgram } & Period I & -0.507 & 0.8851 & -8.777 & $<0.001$ \\
\hline & Period II & -1.100 & 0.7142 & -4.326 & $<0.001$ \\
\hline \multirow[t]{2}{*}{ Greengram } & Period I & 1.206 & 0.9981 & -9.626 & $<0.001$ \\
\hline & Period II & -1.426 & 0.5675 & -6.912 & $<0.001$ \\
\hline \multirow[t]{2}{*}{ Lentil } & Period I & -1.812 & 0.3735 & -7.659 & $<0.001$ \\
\hline & Period II & -1.601 & 0.4748 & -6.929 & $<0.001$ \\
\hline \multirow[t]{2}{*}{ Total Pulses } & Period I & -0.053 & 0.9511 & -6.712 & $<0.001$ \\
\hline & Period II & -1.009 & 0.7485 & -5.459 & $<0.001$ \\
\hline
\end{tabular}

Note: $H_{0}$ : Series has unit root.

After confirming the stationary of series, ARCH-LM Heteroscedasticity test was done for identification of $\mathrm{ARCH}$ effect in residuals. ARCH-LM test perform an auxiliary regression using the residuals from the original equation estimated. The test results presented in Table 2 reject the null hypothesis of no ARCH effect for all the pulse crops and hence confirming the presence of $\mathrm{ARCH}$ effect in the price series of all the pulse crops. Then, the GARCH model was employed to capture volatility in data.

Table 2: Results of heteroskedasticity test

\begin{tabular}{ccccc}
\hline Crops & \multicolumn{2}{c}{ Period I } & \multicolumn{2}{c}{ Period II } \\
& Obs. & Prob. Chi- $^{\text {Obs. }}$ & Prob. Chi- \\
& R-square & Square(1) & R-squared & Square(1) \\
\hline Chickpea & 117.845 & $<0.001$ & 100.932 & $<0.001$ \\
Pigeonpea & 97.530 & $<0.001$ & 111.606 & $<0.001$ \\
Blackgram & 118.027 & $<0.001$ & 108.830 & $<0.001$ \\
Greengram & 121.692 & $<0.001$ & 111.171 & $<0.001$ \\
Lentil & 100.659 & $<0.001$ & 110.125 & $<0.001$ \\
\hline Total Pulses & $\mathbf{1 2 1 . 6 5 2}$ & $<0.001$ & $\mathbf{1 0 7 . 3 9 9}$ & $<\mathbf{0 . 0 0 1}$ \\
\hline
\end{tabular}

Note: $H_{0}$ : there is no arch effect.

ano of observations times the $R^{2}$ from the test regression; ${ }^{b}$ distribution of test statistics.

GARCH $(1,1)$ was selected as the most appropriate model and the summary of the fitted model is given in Table 3. The results of the GARCH analysis clearly indicate that the volatility in the current period depends on volatility in the preceding period in case of pulses as evident from the significant $\mathrm{ARCH}$ term for all the crops in both the periods. The sum of $\alpha$ and $\beta$ coefficients near to one represents the degree of persistence of volatility in the price series but it was found more than one for all the pulse crops except pigeonpea in period I thus indicating an explosive price series with a tendency to meander away from mean value. It implies that the shocks in prices of pulses persist forever and do not reverse to the mean.

Gil-Alana (2014) also found that shocks have a permanent nature in case of arhar and urad as compared to cereals. The Table 3 further shows that the value of $\alpha+\beta$ in case of pigeonpea was 0.86 in sub period I that is near to one indicating that shocks die out rather slowly. It means that shocks to the prices of pigeonpea had the tendency to persist for a longer period but they tend to reverse to the mean in sub period I. This sum has increased to more than one in sub period II indicating the explosive nature of pigeonpea prices in recent period. The sum of $\alpha+\beta$ was found higher for chickpea and pigeonpea in sub period II as compared to sub period I which indicates more explosive price series in recent period compared to the instant past period particularly for pigeonpea. 
Table 3: Parameter estimates of GARCH model

\begin{tabular}{ccccccc}
\hline Crops & \multicolumn{3}{c}{ Period I } & \multicolumn{3}{c}{ Period II } \\
\cline { 2 - 7 } & ARCH $(\alpha)$ & GARCH $(\beta)$ & $\alpha+\beta$ & ARCH $(\alpha)$ & GARCH $(\beta)$ & $\alpha+\beta$ \\
\hline Chickpea & $0.995^{*}$ & 0.124 & 1.119 & $1.340^{*}$ & $-0.217^{* *}$ & 1.123 \\
Pigeonpea & $1.235^{*}$ & $-0.375^{*}$ & 0.860 & $1.187^{*}$ & -0.006 & 1.181 \\
Blackgram & $1.311^{*}$ & $-0.203^{*}$ & 1.108 & $0.760^{* *}$ & $0.337^{*}$ & 1.097 \\
Greengram & $1.155^{* *}$ & -0.068 & 1.087 & $1.013^{* *}$ & 0.015 & 1.028 \\
Lentil & $0.666^{* *}$ & $0.395^{*}$ & 1.061 & $1.070^{*}$ & -0.028 & 1.042 \\
Total Pulses & $1.145^{*}$ & $-0.119^{* * *}$ & 1.026 & $1.219^{* *}$ & $-0.097^{*}$ & 1.122 \\
\hline
\end{tabular}

$*^{* * *},{ }^{* * *}$ indicates significant at 1,5 and 10 per cent level of significance.

\section{ACKNOWLEDGEMENTS}

The author is grateful to Dr. Anil Kumar, Professor, Dept of Agricultural Economics, GBPUA\&T, Pantnagar for providing consistent support and valuable guidance throughout the study and to the UGC for providing fellowship to conduct this study.

\section{CONCLUSION}

Although, India is the largest pulse producing country in the world, the production of these crops in the country has shown sluggish growth over the years. Low growth rate coupled with high fluctuations in production of pulses is mainly responsible for poor performance of pulse sector. It also leads to high price variability. Variability in the prices of pulses is a major concern for decision makers. Price volatility discourage farmers to take up improved production and plant protection methods leading to low production and instability in farmer's income. Price policy in developing countries like India plays an important role in decision making where the agricultural markets have the overarching government presence. The volatility as captured by GARCH $(1,1)$ model was found more than one for all the pulses except pigeonpea in period I thus indicating an explosive series with a tendency to meander away from mean value. This volatility in prices of pulses has increased in sub period II. This implies that the shocks in price system are permanent in nature in case of pulses and do not reverse to the mean over the time. The high volatility largely occurs due to supply shortage, monopolistic behaviour of traders, increase in profit margins, information gap and weak infrastructure. So, there is a need for regular monitoring of prices and appropriate interventions by the government, when necessary, to make the development of pulse sector more sustainable. More researches are needed for proper understanding of agricultural price mechanism specifically in pulses that would help farmers to plan the production and marketing for improved farm profit. There is also a need to study marketing and market infrastructure for pulses in depth for better realisation by farmers and enhanced pulses production in the country.

\section{REFERENCES}

Anuja, A.R., Kar, A., Jha, G.K. and Kumar, R. 2013. Price dynamics and market integration of natural rubber under major trade regimes of India and abroad. Indian Journal of Agricultural Sciences, 83(5): 555-560.

Bhardwaj, S.P., Paul, R.K., Singh, D.R. and Singh, K.N. 2014. An Empirical Investigation of Arima and Garch Models in Agricultural Price Forecasting. Economic Affairs, 59(3): $415-428$

Bisht, A. and Kumar, A. 2018. Growth and Instability Analysis of Pulses Production in India. International Journal of Agriculture Sciences, 10(14): 6722-6724.

Gil-Alana, L.A. and Tripathy, T. 2014. Mean reversion in agricultural commodity prices in India. International Advanced Economic Research, 20: 385-398.

Government of India. 2016. Agricultural statistics at a glance. Directorate of Economics and Statistics, Ministry of Agriculture \& Farmer's welfare, New Delhi.

Upreti, P. 2016. Production efficiency and price behaviour of Sugar in India. Thesis, IARI.

www.eaindustry.nic.in 